\title{
AN EVALUATION OF SECURITY IN THE NIGERIAN AIRPORTS
}

\author{
NWASONUBA, O.C. AND OKEUDO, G.N \\ Department of Transport Management Technology, Federal University of Technology \\ Owerri, Nigeria. \\ Correspondence email: okwukwenwasonuba@gmail.com
}

\begin{abstract}
The air transport industry plays a significant role in the global economy. Secure air transport service enhances connectivity in trade, tourism, political and cultural links between States. The research aims to evaluate airport security at Nigerian airports. And the specific objectives are; to assess passengers' perception of security service in Nigerian airports, determine the effect of airport security on the utility for air travel, and describe the new technologies maximizing airport security as well as proffer possible ways of promoting airport security in Nigeria. The research employed a descriptive survey design relying on a review of literature and questionnaires distributed to respondents to justify the objectives of the research. It was found that security in the Nigerian airport leaves much to be desired, though on the growth path. The research calls for increased security consciousness in the Nigerian Airport given the security challenges, especially the Boko Haram insurgence bedeviling the country, and required that the government embrace new and innovational trends in aviation security to maximize airport security in the country.
\end{abstract}

Key Words: Airport Security, Air Transport, Evaluation, FAAN, Nigerian Airports. 


\section{Introduction}

Transport has played a catalytic role in the movement of people, goods, and services, leading to the economic and social transformation of many nations. Development and diversification of the transport system have had a cause for expansion, intensification of production, and circulation of goods. With each stage of development of human society, a certain mode of transport has been developed or adapted (Nistor \& Popa, 2014). Air transport is one of the fastest modes of public transport which connects international boundaries. Air transport allows people from different countries to cross international boundaries and travel to other countries for personal, business, medical, and tourism purposes. Although air transport provides the fastest means by saving the time of journey, another very important aspect is the facilities and comfort level of the passengers (Tiwari \& Prasad, 2019).

The air transport mode is defined by four basic elements: airlines, commercial transport aircraft, the air space used for their flights, and the infrastructure required to supporting their operations, like airports and ATM (Air Traffic Management) facilities (Benito and Alonso (2018). Air Transport Infrastructure integrates all the ground facilities needed to support airline services with adequate levels of safety, reliability, and economy. The two main elements of those facilities are airports and air navigation services. Airports are ground infrastructures, placed generally close to the cities they serve, acting as interchange centers of different transport modes and including many commercial services that take advantage of the great number of passengers going in and out through the terminals. Air transport infrastructure collaborates to optimize the performance of the flights, trying to adapt flight itineraries to the operating aircraft and routes requirements, and minimizing delays both in flight and on the ground (Benito and Alonso.2018).

While flying has always been one of the safest ways to travel, thanks to its wideranging international regulatory frameworks, aviation incidents have an outsize impact on the public consciousness. From recent airport attacks in Brussels and Istanbul to the shooting down of MH17 over Ukraine, horrifying images are more powerful than reassuring statistics (Kaspersen, 2016). Aviation is a target for terrorists intent on destroying the freedom that is at the heart of the business, and socioeconomic activities. Since the dawn of commercial aviation, terrorists have used the air transportation system to both commit their attacks and to attack the system as a target in its own right. Airports in particular have stood out as relatively 'soft' targets for terrorist attacks. While aircraft have been hardened as targets over recent decades with the gradual addition of enhanced security measures, airports by nature have had to remain in public areas, at least partly accessible to anyone, hence making them preferred targets (Duchesneau \& Langlois, 2017). Perpetrators have used the full range of possibilities to attack airports, from mass killings using grenades and automatic weapons to small homemade bombs exploding in parking lot garbage bins without injuring anyone. Attacking an airport is generally viewed as a substitute for attacks on airliners - a "poor's man's" hijacking, a simpler way to make a political point without running the risks (Jenkins, 1989). Airport attacks are acts in which individuals or installations on airport grounds are violently and specifically targeted. Targets can include terminals, check-in counters, boarding gates, passenger areas, vehicles, parking lots, and other equipment or buildings, but excluding aircraft themselves. 
Terrorist groups perceive attacks against international civil aviation as an effective way to cause substantial loss of life, economic damage, and disruption. Because of the global and interconnected nature of the international civil aviation industry, the Member States of all regions are potentially vulnerable to such attacks (Counter-Terrorism Committee Executive Directorate [CTED], 2017). CTED, (2017) expressed particular concern that terrorist groups may be actively seeking ways to defeat or circumvent international civil-aviation security measures and to identify and exploit perceived gaps or weaknesses and stressed the need for States to introduce appropriate countermeasures. Recent attacks against airports in Belgium, Turkey, and the United States, the explosion of a terrorist bomb aboard Daallo Airlines flight 159 , and other recent terrorist attacks according to the council are stark reminders of landside attacks, the threat posed by insiders and airport staff, and the use of increasingly sophisticated improvised explosive devices are all significant concerns. The international aviation sector also faces several new and emerging security risks and threats. The use of information technology (IT) for malicious purposes is a global threat. The global civil aviation community depends on IT systems for its daily operations, and as that dependence continues to grow, critical civil aviation infrastructures will become increasingly vulnerable to malicious IT-based attacks.

\section{Current Challenges and Future Trends of Airport Security}

According to the Statista website, commercial airlines carried an estimated 4.3 billion passengers on scheduled flights in 2018 , with more than 4.5 billion people anticipated to fly in 2019. In 2009, nearly 2.5 billion passengers flew commercially, meaning airlines and airports have seen a passenger traffic increase of 80 percent, or 2 billion people, over the last 10 years. The increase in airline passenger traffic brings many challenges with it, such as just how airports, aviation security companies, and government transportation security agencies will efficiently handle so many travelers.

In truth, airports are already bursting at the seams in terms of passenger traffic, and airports and airlines will need to be at the top of their game to handle billions of more passengers annually. Airport and aviation security infrastructure will also present significant challenges to airports in the future, especially those in the U.S. As noted by research, how increased airline passenger traffic will be smoothly and efficiently processed through airport security checkpoints pose an urgent problem. Fortunately for airports and airlines as well as government transportation security agencies, improved aviation security technologies now exist. These technologies can serve as a stopgap to enhance passenger security screening numbers until a more permanent security infrastructure, especially regarding permanent facilities, is created.

In the U.S., research shows that the Transportation Security Agency has been working on several passenger screening technology improvements. Facial recognition and advanced imaging technologies, to name just two initiatives, hold the promise of being able to process many more airline passengers through TSA checkpoints than is currently the case. TSA has also rolled out automated screening lanes, or ASLs, at over 16 major airports, with more to come as the technology proves itself. These ASLs incorporate an array of innovative technologies that not only enhance the passenger security experience but also provide better security faster. Many of the screening functions that were previously performed manually are now completed via automated processes and with very impressive accuracy rates.

Overseas as well as in the U.S., other technologies that are greatly speeding passenger security screening and reducing lines include Thruvision's next-generation people screening 
products. The company's TSA-vetted and approved technologies can process between 500 and 2,000 people per hour, depending on associated consolidated operations ("Con-Ops"). The system also detects all types of prohibited items, no matter how small or discretely concealed they are. What's particularly impressive about Thruvision's tech is that it doesn't require any physical searching of passengers and can be set up and then disassembled and rapidly moved to other areas at airports and various venues when needed.

New technologies are changing the security landscape. Several airports are now running remote security screening. Integration of security systems is proving challenging at all levels. At the organizational level, new technologies have implications for future recruitment, training, and workforce structures. From a wider security perspective, there remains a divide between cyber and physical security within organizational structures, a separation not recognized by those seeking to disrupt our operations. Finally, was seen at a screening level, particularly with mass public screening landside, a need for a better understanding of how different technologies, processes, and skills should be integrated for best effect (International Airport Review, 2017)

\section{Empirical Evaluation of Airport Security}

There is a paucity of study into security in Nigerian airports, however, few scholars have tried to examine elements relating to security at the airport terminals. A study by Ryoichi et al., (2016). Analyses the perception of airport safety by travelers, and how it is related to satisfaction with passenger screening experiences and the perception of public transit safety. It uses the Omnibus Household Survey data collected by the U.S. Bureau of Transportation Statistics and estimates a structural equations model. It finds a positive relationship between Screening Satisfaction and Screening Safety and a positive relationship between the perception of Public Transit Safety and Screening Safety. A lack of experience with using public transit is also found to contribute to travelers perceiving lower levels of Screening Safety at airports, and females compared to males perceive a lower level of Screening Safety.

Suleiman (2012) examined air transportation in Nigeria and discovered that there is loose security at airports in Nigeria, with the absence of solid perimeter fencing at some airports in the country, which allowed grazing by the runway of some airports. For example, in 2005 an Air France flight crashed on cows on the runway of Port Harcourt International Airport, killing seven of them and damaging the landing gear of the aero plane (Agbo, 2008). Besides, the roads leading to some airports such as those at Owerri and Port Harcourt are not secured, as armed robbers and militants attack travelers (Agbo, 2008). The Isolo Expressway leading to Lagos International airport also witness armed robbery incidents. These robbery incidents occur due to loose security along roads leading to airports that need to be secured for the safety of travelers and their properties. There are also petty thieves in some airports who capitalize on the loose security to break into visitor's cars and carry handy belongings (Suleiman, 2012).

Abraham, Obioma, Ogunnumesi, and Imad (2017) examined the effect of airport touting from passenger's perspective using the NnamdiAzikiwe Airport Abuja. Using several analytical tools such as descriptive, multiple regressions analysis, and one-way analysis of variance (ANOVA) to assess identifiable characteristics. A self-administered questionnaire was designed to capture responses from both passengers and touts, to obtain a balanced view on the issue. Around two hundred (200) were distributed across two terminals, one hundred and eighty (180) responses were retrieved back. The results revealed that most of the touts 
operating at this airport were males, while only a quarter were females, only a few of them had higher education. They engaged themselves in all sort of activities carry passenger's luggage, make a reservation for their taxis and hotels, purchase and resell airline tickets at the airport. Besides, they extorted money and collect illegal fees from passengers, engaged in stealing and intimidating passengers, and most of them sampled were pleased with the profession. The majority of passengers sampled were unsatisfied with the touts' activities and the current law on touting.

It is seen from the previous works covered that security around and inside the airports requires an evaluation with aim of better positioning the airports to serve the users better, ensuring proper security of life, valuables, and the safety of the overall operations on the airport as an invaluable transportation terminal.

\section{Methodology}

The study adopted a descriptive survey design which is most appropriate where the study seeks to describe the characteristics of certain groups and as well estimate the proportion of people who make certain predictions. The design was chosen for this study due to its ability to ensure minimization of bias and maximization of reliability of evidence collected. This research sought to gain information from the airport users in Nigeria, particularly, Muritala Muhammed International Airport (MMIA) Lagos as it relates to issues by the current study. The Muritala Muhammed International Airport Lagos (MMIA) was chosen as it commands the highest passenger traffic among every other airport in the country. Security as well is highly beefed up at the airports given its strategic position in the international movement of passengers and freight services, leading to intense operational activities and a myriad of other airport services.

According to Mugenda (1999), the target population is defined as "The totality of cases of people, organization or institutions which pose certain common characteristics that are relevant to the study". This research sought to gain information from the airport users in Nigeria as it relates to issues by the current study. A survey of the airport security services and security infrastructure of the airport is the basis for the justification of the objective of the study. Primary data was obtained through the use of structured interviews and questionnaires. The questionnaire was pre-tested to check that it would collect relevant information and that the wording was clear. The responses from this pilot study were analyzed and the feedback was used to improve the wording of the final research questionnaire. The questionnaires were administered for a week through face-to-face interviews with respondents. The result was presented using inferential statistics arranged in frequency tables and percentages.

\section{Results and Discussion}

\subsection{Questionnaire Analysis}

Questionnaires were required in the study as an instrument for primary data collection as required in the study. The questionnaires were completed by 201 respondents comprising the passengers traveling through the international airport, it was also important to note that more than $60 \%$ of the respondents had flown on international flights for at least 5 years. This is aimed to minimize research bias and to ensure the research objectives were duly justified. The questionnaire by the end of fieldwork was screened for eligibility, out of 400 questionnaires that were designed and distributed, a total of 201questionnaires were received, 190 were rejected because they were not filled properly, and the 201 that was left was used to carry out the statistical analysis. Table 1 below presents an analysis of the questionnaire. 
Journal DOI: www.doi.org/10.46654/AJBED

Vol. 1, Issue 5 (May, 2021)| www.ijaar.org

Article DOI: www.doi.org/10.46654/AJBED.1513

Table 1; Questionnaire Analysis

\begin{tabular}{|l|l|l|}
\hline Questionnaire & Quantity & Percentage \\
\hline Distributed & 400 & $100 \%$ \\
\hline Valid & 201 & $51 \%$ \\
\hline
\end{tabular}

Source; fieldwork, 2019

\subsection{Data Presentation and Description}

A general summary of respondents' responses to certain questions in the questionnaires and a few information of the respondent is presented and described below, it is also important to note that the information and responses of the respondents were categorized according to the airport used for the study.

\subsubsection{Demographic Distribution of Respondents by Age and Sex}

The summary of the spread, showing the frequency and percentages of the age and sex of respondents based on the range was presented in both table and figure.

Table 2: Age Distribution of Respondents

\begin{tabular}{|l|l|l|l|}
\hline Age & Frequency & Percent & Cumulative Percent \\
\hline $18-24$ & 37 & 18.4 & 18.4 \\
$25-35$ & 61 & 30.3 & 45.7 \\
$36-50$ & 60 & 29.9 & 75.6 \\
$50+$ & 43 & 21.4 & 100.0 \\
Total & 201 & 100.0 & 100.0 \\
\hline
\end{tabular}

(Field Survey, 2019)

The information in Table 1 was presented in Figure 1 for better understanding. Thus, Figure 1 shows that the respondents are either 18 years of age or above. 


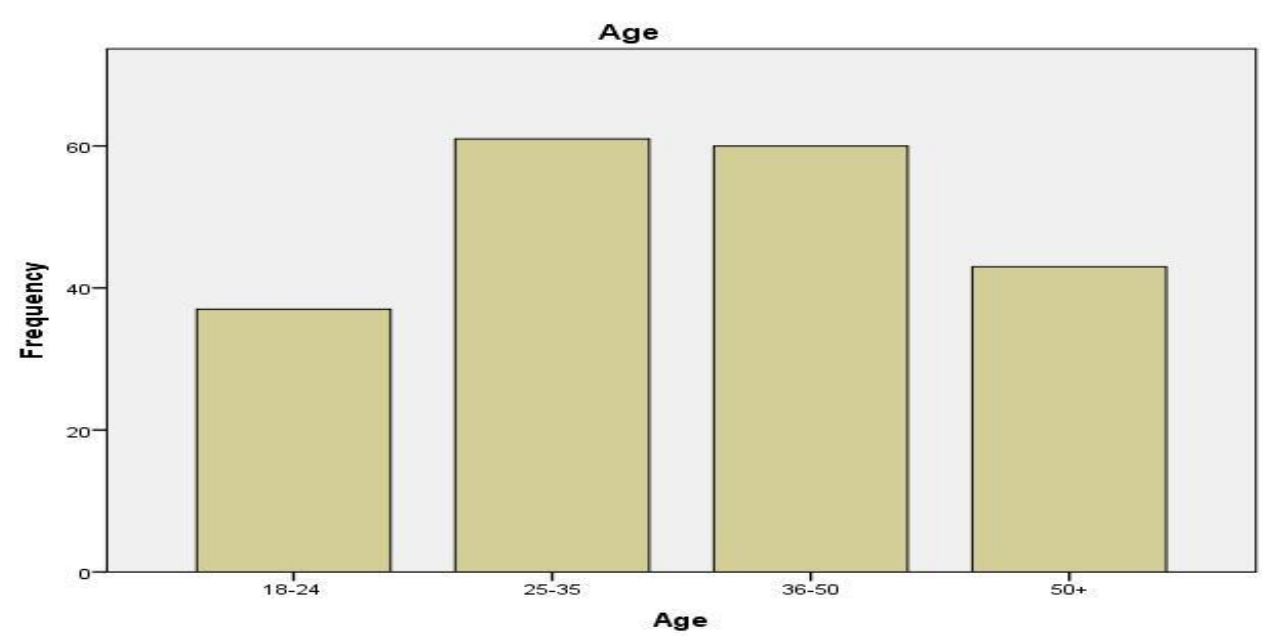

Figure 1: Age Distribution of the Respondents (Field Survey 2019)

Table 3: Gender Distribution of Respondents

\begin{tabular}{|c|c|c|c|c|}
\hline Gender & Frequency & Percent & Valid Percent & Cumulative Percent \\
\hline Male & 117 & 58.2 & 58.2 & 58.2 \\
\hline Female & 84 & 41.8 & 41.8 & 100.0 \\
\hline Total & 201 & 100.0 & 100.0 & 100.0 \\
\hline
\end{tabular}

(Field Survey 2019)

The distribution in Table 2 shows that male has a slight dominance over the female. This is understandable as men tend to travel more than women especially in Lagos state where commerce is very high. The summary in percentage was further explained in Figure 2.

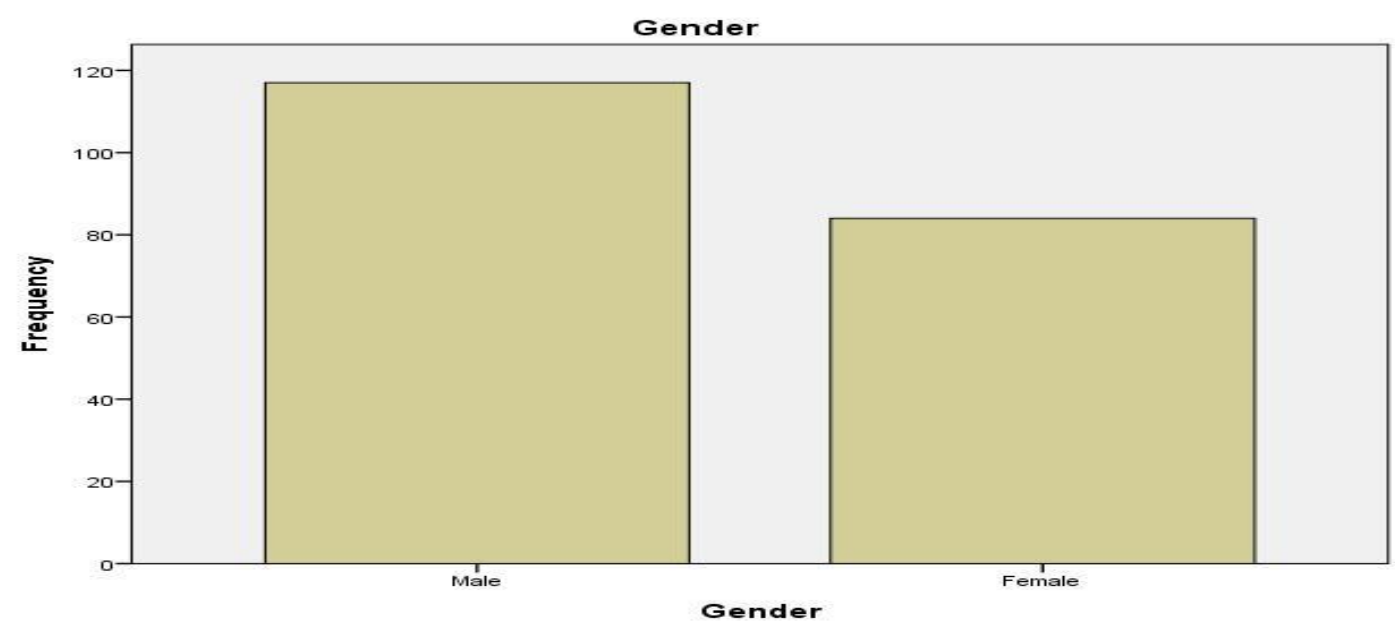

Figure 2: Gender Distribution of the Respondents (Field Survey, 2019) 


\subsubsection{Analysis of the Objectives of Study Based on Security in the Airports}

The summary of the spread, showing the frequency and percentages of the respondents based on their responses to a structured question with the objectives were presented in both tables and figures.

\section{Table 4: Airport Users' Perception on Level of Security in Term of Equipments and Personnels in the Nigerian Airports}

\begin{tabular}{|l|l|l|l|l|}
\hline Research Questions & Scale & Frequency & Percentage & $\begin{array}{l}\text { Cumulative } \\
\text { Percentage }\end{array}$ \\
\hline $\begin{array}{l}\text { 1. Nigerian airports have standard perimeter } \\
\text { fencing to guide against the illegal entrance } \\
\text { and access to the runway }\end{array}$ & Strongly Disagree & 106 & 53.0 & 53.0 \\
\cline { 2 - 5 } & Disagree & 45 & 22.0 & 75 \\
\cline { 2 - 5 } & Undecided & 14 & 7.0 & 82.0 \\
\cline { 2 - 5 } & Agree & 24 & 12.0 & 94.0 \\
\cline { 2 - 5 } & Strongly Agree & 12 & 6.0 & 100.0 \\
\cline { 2 - 5 } & Total & $\mathbf{2 0 1}$ & $\mathbf{1 0 0 . 0}$ & \\
\hline \multirow{2}{*}{$\begin{array}{l}\text { 2. The equipment available is of the latest } \\
\text { technology and adequate to maintain } \\
\text { standard security }\end{array}$} & Strongly Disagree & 60 & 30.0 & 30.0 \\
\cline { 2 - 5 } & Disagree & 45 & 22.0 & 52.0 \\
\cline { 2 - 5 } & Undecided & 14 & 7.0 & 59.0 \\
\cline { 2 - 5 } & Agree & 40 & 20.0 & 79.0 \\
\cline { 2 - 5 } & Strongly Agree & 42 & 21.0 & 100.0 \\
\cline { 2 - 5 } & Total & $\mathbf{2 0 1}$ & $\mathbf{1 0 0 . 0}$ & \\
\hline \multirow{3}{*}{$\begin{array}{l}\text { 3. Security personnel are well trained } \\
\text { morally and otherwise to provide airport }\end{array}$} & Strongly Disagree & 99 & 49.0 & 49.0 \\
\cline { 2 - 5 } users with quality service. & Disagree & 45 & 22.0 & 71.0 \\
\cline { 2 - 5 } & Undecided & 17 & 9.0 & 80.0 \\
\cline { 2 - 5 } & Agree & 24 & 12.0 & 92.0 \\
\cline { 2 - 5 } & Strongly Agree & 16 & 8.0 & 100.0 \\
\cline { 2 - 4 } & Total & $\mathbf{2 0 1}$ & $\mathbf{1 0 0 . 0}$ & \\
\hline
\end{tabular}

(Field Survey, 2019)

The distribution in Table 3 shows that majority of the users strongly disagreed that, the airport perimeter is properly fenced to ensure there is no illegal entrance and access to the runway of the Nigerian airports. Similarly, a great number of the respondents disagree that equipment available in Nigerian airports is of the latest technology and adequate to maintain standard security. While almost $50 \%$ of the respondents strongly disagree that security personnel is well trained morally and otherwise to provide airport users with quality service.

In summary, over $50 \%$ of the targeted population of the respondents strongly disagree and disagree with being satisfied with the overall level of security present at the airport. This shows that passengers perceive security screening as being very poor and lackluster, this is a worrying sign as this shows that they are loopholes that can be exploited in doing so putting lives and properties at risk. 
Table 5: The effect of airport security on the utility of air travel

\begin{tabular}{|c|c|c|c|c|}
\hline Research Questions & Scale & Frequency & Percentage & $\begin{array}{l}\text { Cumulative } \\
\text { Percentage }\end{array}$ \\
\hline \multirow{6}{*}{$\begin{array}{l}\text { 4. The level of security consciousness by } \\
\text { security personnel is adequate for travelers' } \\
\text { safety. }\end{array}$} & $\begin{array}{l}\text { Strongly } \\
\text { Disagree }\end{array}$ & 104 & 52.0 & 52.0 \\
\hline & Disagree & 43 & 22.0 & 74.0 \\
\hline & Undecided & 15 & 8.0 & 82.0 \\
\hline & Agree & 23 & 11.0 & 93.0 \\
\hline & Strongly Agree & 16 & 8.0 & 100.0 \\
\hline & Total & 201 & 100.0 & \\
\hline \multirow[t]{6}{*}{$\begin{array}{l}\text { 5. The security present at the airport is } \\
\text { adequate to combat any security threat }\end{array}$} & $\begin{array}{l}\text { Strongly } \\
\text { Disagree }\end{array}$ & 60 & 30.0 & 30.0 \\
\hline & Disagree & 54 & 27.0 & 57.0 \\
\hline & Undecided & 33 & 16.0 & 73.0 \\
\hline & Agree & 37 & 18.0 & 91.0 \\
\hline & Strongly Agree & 17 & 9.0 & 100.0 \\
\hline & Total & 201 & $\mathbf{1 0 0 . 0}$ & \\
\hline \multirow[t]{6}{*}{$\begin{array}{l}\text { 6. Perceived airport insecurity would affect } \\
\text { the choice of travel }\end{array}$} & $\begin{array}{l}\text { Strongly } \\
\text { Disagree }\end{array}$ & 105 & 52.0 & 52.0 \\
\hline & Disagree & 45 & 22.0 & 74.0 \\
\hline & Undecided & 14 & 7.0 & 81.0 \\
\hline & Agree & 24 & 12.0 & 93.0 \\
\hline & Strongly Agree & 15 & 7.0 & 100.0 \\
\hline & Total & 201 & 100.0 & \\
\hline
\end{tabular}

(Field Survey, 2019)

The analysis in Table 4 above shows that over $50 \%$ of the respondents strongly disagree that the level of security consciousness by security personnel is adequate for travelers' safety. Also, 57\% of the respondents cumulatively disagree and strongly disagree that security present at the airport is adequate to combat any security threat. While $74 \%$ of the respondents cumulatively disagree that perceived insecurity in the Nigerian airports would affect the choice of travel.

In sum, perceived insecurity in the Nigerian airports in terms of lack of security consciousness and security gadgets will affect the passengers' utility for air travel. Hence, it will give room for passengers to consider other modes of transport such as road as well as rail transport which is already moribund in the country. Invariably this will lead to a rise in the pressure already existing on the road due to an upsurge in road traffic as air traffic would to a large extent be diverted to the road. Consequently, road accidents and other insecurity issues characterized by road transport in the country would be on the increase. 
Table 6:The possible ways of improving security in the Nigerian Airport

\begin{tabular}{|c|c|c|c|c|}
\hline Research Questions & Scale & Frequency & Percentage & $\begin{array}{l}\text { Cumulative } \\
\text { Percentage }\end{array}$ \\
\hline \multirow[t]{6}{*}{$\begin{array}{llll}\text { 7.Significant investment in new } \\
\text { technologies }\end{array}$} & $\begin{array}{l}\text { Strongly } \\
\text { Disagree }\end{array}$ & 10 & 5.0 & 5.0 \\
\hline & Disagree & 20 & 10.0 & 15.0 \\
\hline & Undecided & 18 & 9.0 & 24.0 \\
\hline & Agree & 53 & 26.0 & 50.0 \\
\hline & Strongly Agree & 100 & 50.0 & 100.0 \\
\hline & Total & 201 & 100.0 & \\
\hline \multirow{6}{*}{$\begin{array}{l}\text { 8. Protection of airport infrastructure } \\
\text { through the use of surveillance and } \\
\text { monitoring systems }\end{array}$} & $\begin{array}{l}\text { Strongly } \\
\text { Disagree }\end{array}$ & 8 & 4.0 & 4.0 \\
\hline & Disagree & 13 & 6.0 & 10.0 \\
\hline & Undecided & 36 & 18.0 & 28.0 \\
\hline & Agree & 44 & 22.0 & 50.0 \\
\hline & Strongly Agree & 100 & 50.0 & 100.0 \\
\hline & Total & 201 & 100.0 & \\
\hline \multirow[t]{6}{*}{$\begin{array}{l}\text { 9. Provision of screening, scanning, and } \\
\text { tracking devices }\end{array}$} & $\begin{array}{l}\text { Strongly } \\
\text { Disagree }\end{array}$ & 4 & 2.0 & 2.0 \\
\hline & Disagree & 12 & 6.0 & 8.0 \\
\hline & Undecided & 20 & 10.0 & 18.0 \\
\hline & Agree & 45 & 22.0 & 40.0 \\
\hline & Strongly Agree & 120 & 60.0 & 100.0 \\
\hline & Total & 201 & 100.0 & \\
\hline
\end{tabular}

(Field Survey, 2019)

The analysis on the table above shows that about $74 \%$ of the respondents strongly agree and agree that significant investment in new technologies is desirable to curtail security threats in Nigerian airports. Thus, the evolving nature of the security threats facing the aviation industry will require significant investment in the development of new technologies and have implications for overall security planning procedures.

Similarly, over $50 \%$ of the respondents believe that the protection of airport infrastructure through the use of surveillance and monitoring systems will help to forestall security threats. Thus, screening, scanning, and tracking devices arean area where technological innovations are adding to combined identification solutions for goods and persons. Biometric technologies can automate the identification of people by one or more of their distinct physical or behavioral characteristics. The main types of biometric data include fingerprints, face recognition, iris recognition, and vascular recognition. The protection of airport infrastructure through enhanced (and intelligent) surveillance systems will go a long way to combat surety threats. 
Over $80 \%$ of the respondents agree and strongly agree that the provision of screening, scanning, and tracking devices will help to checkmate security threats in Nigerian airports. Thus, protection of airport infrastructure is a key aim of aviation security systems relating to the protection of airport infrastructure is to control the access of people moving into or out of protected areas, such as physical buildings, sensitive areas within airport terminals, and information systems through the use of surveillance and monitoring systems. Surveillance is a central element of airport security management and takes place through several means, from intelligent video surveillance to the use of biometric tools for checking the identity of airport workers with secure access rights.

Table 7; Analysis of Passengers Perception of Airport Security

\begin{tabular}{|l|l|l|l|l|l|}
\hline & $\begin{array}{l}\text { Very } \\
\text { Unsatisfied }\end{array}$ & Unsatisfied & Undecided & Satisfied & $\begin{array}{l}\text { Very } \\
\text { Satisfied }\end{array}$ \\
\hline Screening process & $55 \%$ & $25 \%$ & $5.00 \%$ & $7.00 \%$ & $8.00 \%$ \\
\hline $\begin{array}{l}\text { Attitude of security } \\
\text { personnel }\end{array}$ & $\mathbf{2 4 . 4 0 \%}$ & $\mathbf{3 6 . 8 0 \%}$ & $\mathbf{9 . 8 0 \%}$ & $\mathbf{1 8 . 7 0 \%}$ & $\mathbf{1 0 . 4 0 \%}$ \\
\hline $\begin{array}{l}\text { Security facilities and } \\
\text { equipment }\end{array}$ & $\mathbf{6 0 . 0 0 \%}$ & $\mathbf{2 0 . 0 \%}$ & $\mathbf{8 . 6 0 \%}$ & $\mathbf{3 . 0 0 \%}$ & $\mathbf{8 . 4 0 \%}$ \\
\hline Overall security & $\mathbf{5 2 . 7 \%}$ & $\mathbf{2 2 . 4 \%}$ & $\mathbf{7 . 0 0 \%}$ & $\mathbf{1 1 . 9 \%}$ & $\mathbf{6 . 0 0 \%}$ \\
\hline
\end{tabular}

Source; authors fieldwork, 2020

Table 7 above presents an analysis of the passengers' opinions regarding their level of satisfaction with the security status of the airport. Regarding the passenger and luggage screening process, the majority of the passengers representing $55 \%$ of the total respondents expressed dissatisfaction over the security screening process at the airport. The passengers as well are not satisfied with the attitude of the security personnel's towards their job as they attend to passengers for security screen. A majority of the respondents, $36.8 \%$ showed dissatisfaction with this. As per security equipment, the majority of the respondents, $60 \%$ of the total respondents also expressed dissatisfaction over the nature of the security facilities and equipment used in the airport.

This goes to say that security at the airport leaves much to be desired. given that most of the passengers considered in the research are international passengers who had used other airports of the world; both in developed and other third world countries. One would conclude that their judgment is based on what is obtainable in other countries of the world. Nigeria airport security when compared to developed countries airport could be said to be well below expectation. This would explain while the majority of the passengers are not satisfied with the security situation in the airports. As it were, only a few, $11.9 \%$ and $6.0 \%$ of the average response are very much satisfied with overall security at the airport. Those who differ in opinion, although a few, showing satisfaction to the security status of the airport could have their judgment spring from their experience with what is obtainable in other undeveloped countries. In their opinion, Nigeria deserves some commendation. 


\section{Conclusion}

The air transport industry plays a significant role in the global economy. Secure air transport service enhances connectivity in trade, tourism, political and cultural links between States. Because of this, the study evaluates airport security in the Nigerian airports with Muritala Muhammed International Airport Lagos in focus. The objectives were; to examine airport users' perception of the level of security in terms of equipment and personnel in Nigerian airports; determine the effect of airport security on the utility of air travel, and proffer possible ways of promoting airport security in Nigeria. To achieve the stated objectives, data from a primary source through a questionnaire and in-depth oral interview was utilized. A total of two hundred and one (201) questionnaires which were properly completed by users of the air transport facilities was used for the analysis. The questionnaire was designed with the use of Likert's 5-scale model of Strongly Agreed, Agreed;Undecided, Disagreed, and Strongly Disagreed. The collected data was analyzed with the simple percentage method. Based on the empirical results, it was found that security in the Nigerian airport does not exhibit the high level of professionalism required of their job. The security facilities and equipment at the airport also do not meet passengers' expectations. They are not enough to service the airport security need efficiently. Many new modern security innovations are yet to be seen and employed in the Nigerian airport. Thus, the overall security service situation of the Nigerian airport is very unsatisfactory and needs to be improved towards international competition. The utility to travel by air is greatly impacted by perceived airport insecurity.Deduction from the foregoing analysis would mean that the Nigerian airport is on the growth path. Although she is not yet there in terms of security, there exists hope and capability for a better future.

Based on the conclusions of the research, the following recommendations were deemed necessary;

Security at the airport must be approached with utmost seriousness and dogged commitment to ensuring the safety of passengers, airport infrastructures, and the economy. The Nigerian government must give due attention to the training and retraining of the airport personnel. This is because human intelligence has been acknowledged as the most basic resource in combating insecurity. Training is also necessary to shape the attitude of the security personnel towards security consciousness and alertness. The security personnel as well needs see their job as a service to humanity and not just a means to an end. This is because they must understand that the wealth of the nation by their service and the safety of lives of many to a large extent is entrusted to their hands. Federal Airports Authority of Nigeria (FAAN) should embrace and invest in new security measures and modern devices developed to stop more elaborate and intelligently planned actions by terrorists. 


\section{REFERENCES}

Abraham, P, Obioma, R.N., Ogunnumesi, O. \&Imad, G. (2017). An investigation into the effect of airport touting from the passengers' perspective: A case of NnamdiAzikiwe Airport Abuja, Transportation Report Pocedia, 28,69-78

Agbo, A. (2008). Back with a But, Cover Story TELL, Nigeria's independent weekly Vol. 1 January 2008

Aviation Analysts International (2019). How can technology improve airport security and safety? http://www.inter-aviation.com/how-can-technology-improve-airport-securityand-safety/

Benito, A. \& Alonso, G. (2018). Air transport infrastructure. Retrieved on $24^{\text {th }}$ of August, 2019 via www.sciencedirect.com/topics/engineering/air-transport

Benito, A.\&Alonso, G. (2018). The elements of the air transport system. https://www.sciencedirect.com/topics/engineering/air-transport

Counter-Terrorism Committee Executive Directorate. (2017). A special meeting of the Counter-Terrorism Committee on "Terrorist Threats to Civil Aviation". https://www.un.org/sc/ctc/wp-content/uploads/2017/06/Aviation-concept-note-

Duchesneau, J. \&Langlois, M. (2017). Airport attacks: The critical role airports can play in combatting terrorism. Journal of Airport Management. 4, 342-354.

Effects of the Global Economic Crisis on the Civil Aviation Industry, Geneva,20- 2Air Transport Action Group (2018). Aviation benefits beyond borders: Employment. Retrieved from https://aviationbenefits.org, on 14/4/182February.www.ilo.org/wcmsp5/groups/public

ICAO (nd). International Civil Aviation Organization: Ripple's prosperity. Accessed from https://www.icao.int/sustainability/documents/econcontribution.pdf on 9/4/18 ILO (2013). Civil aviation and its changing world of work. Issues paper at the Global Dialogue Forum on the

ICAO. (2017). Global aviation security plan. https://www.icao.int/SAM/Documents/2018USAPCMA/Global_Aviation_Security_Plan_November_2017_en.pdf

International Airport Review. (2017). Airport security: current challenges and trends

Kaspersen, A. (2016). Four threats to aviation security - and four responses. Retrieved via https://www.weforum.org/agenda/2016/07/four-threats-to-aviation-security-and-fourresponses/

New Telegraph (2017). Aviation as a catalyst for Nigeria's growth. Retrieved from file:///E:/Aviation as the catalyst for Nigeria growth.html, on 20/2/18 
Journal DOI: $\underline{w w w . d o i . o r g / 10.46654 / A J B E D ~}$

Vol. 1, Issue 5 (May, 2021) |www.ijaar.org

Article DOI: www.doi.org/10.46654/AJBED.1513

Oxford Economic (2012). Benefits from air transport in Nigeria: Nigeria report. Retrieved from www.oxfordeconomics.com on 13/4/18

Tiwari, P. \&Prasad, M. (2019). Sentiment Analysis for Airlines Services Based on Twitter Dataset. https://www.sciencedirect.com/topics/engineering/air-transport

Suleiman, I.L. (2012). An analysis of air transportation in Nigeria, JORIND 10 (2), 230-237 